\title{
Exposure as Collected Fasting Status
}

National Cancer Institute

\section{Source}

National Cancer Institute. Exposure as Collected Fasting Status. NCI Thesaurus. Code C117492.

An indication or description of whether a collected exposure specimen was obtained from a subject that has abstained from food and possibly water for the prescribed amount of time. 